\title{
Abo Blood Variants of Selected Babcock University Students and Their Link with Malaria Parasitaemia
}

\section{Otajevwo Festus Dafinone*, Owodunni Olasope Mumeen}

Department of Bioscience and Biotechnology, Babcock University, Ilishan Remo, Nigeria

Email address:

fesdotaj@yahoo.com(O.F. Dafinone)

*Corresponding author

\section{To cite this article:}

Otajevwo Festus Dafinone, Owodunni Olasope Mumeen. Abo Blood Variants of Selected Babcock University Students and Their Link with Malaria Parasitaemia. Pathology and Laboratory Medicine. Vol. 2, No. 1, 2018, pp. 5-14. doi: 10.11648/j.plm.20180201.12

Received: March 16, 2017; Accepted: April 28, 2017; Published: May 9, 2018

\begin{abstract}
Five milliliters $(5 \mathrm{ml})$ of venous whole blood was collected from one hundred and eighty three students made up of 93(50.8\%) male and 90(49.2\%) female students of Babcock University, Ilishan Remo randomly selected across various Departments. Whole blood samples were dispensed into sequestrinized (EDTA anticoagulated) blood containers, properly mixed and labeled. Malaria Plasmodium falciparum parasite screening was done semi-quantitatively by Field stain A and B staining. ABO blood phenotyping was carried out with monoclonal Antisera A, B and D. A total of 169 (92.3\%) and 14(7.7\%) students were rhesus positive and negative respectively of which 92(54.4\%) and 77(45.6\%) samples were rhesus positive male and female students respectively and of which $1(7.1 \%)$ and $13(92.9 \%)$ students were rhesus negative male and female students respectively. One hundred and thirty five (73.8\%), 36(19.7\%) and 12(6.5\%) of the sampled student population belonged to 1720, 21-24 and 25-30yr age brackets respectively. One hundred and ten (60.1\%), 38(20.8\%), 29(15.9\%) and 6(3.3\%) students were of $\mathrm{O}, \mathrm{A}, \mathrm{B}$ and $\mathrm{AB}$ blood phenotypes respectively. Out of the 183 blood samples obtained from 93 (50.8\%) and 90(49.2\%) male and female students respectively, 126(68.9\%) students were infected with P. falciparum malaria parasites. More males were infected than females and were significantly associated with malaria infection $\left(\mathrm{X}^{2}{ }_{0.05,1}=3.841\right.$, Cal. $\mathrm{X}^{2}$ $=25.253, \mathrm{P}<0.05)$. Also, out of the $68.9 \%$ infected students, $47(37.3 \%)$ and $79(62.7 \%)$ had severe and non-severe forms of malaria infection respectively. Severe malaria frequency occurrences were $85.0 \%, 70.6 \%, 50.0 \%$ and $50.0 \%$ for blood types A, $\mathrm{O}, \mathrm{B}$ and $\mathrm{AB}$ respectively while non-severe malaria frequency occurrences were $83.3 \%, 75.0 \%, 65.8 \%$ and $57.9 \%$ with respect to blood types $\mathrm{A}, \mathrm{AB} O$ and $\mathrm{B}$ respectively. $\mathrm{ABO}$ blood types especially type $\mathrm{A}$ were significantly associated with severe form of $P$. falciparum malaria infection $\left(\mathrm{X}_{0.05,3}^{2}=7.815, \mathrm{X}_{0.01,3}^{2}=11.350\right.$, Cal. $\mathrm{X}^{2}=284.601$ and $\left.\mathrm{P}<0.05, \mathrm{P}<0.01\right)$. ABO blood types were also significantly associated with non-severe form of malaria especially type $\mathrm{A}\left(\mathrm{Cal} . \mathrm{X}^{2}=230.768\right.$ and hence, $\mathrm{P}<0.05$, $\mathrm{P}<0.01)$. Implications of rising trend of rhesus negative factor in female students, population variations in association with $\mathrm{ABO}$ blood types and malaria parasitaemia are discussed.
\end{abstract}

Keywords: ABO Variants, Link, Malaria Infection, Students, University

\section{Introduction}

ABO blood types was the first human blood group discovered in 1901 by Landsteiner followed by Rh blood group in 1941 [1, 2]. About thirty major blood groups have been recognized by The International Society of Blood Transfusion (ISBT) and among these thirty are the ABO and $\mathrm{Rh}$ blood groups [3, 4]. The $\mathrm{ABO}$ system is the most investigated erythrocyte antigen system for all populations and due to the ease of identifying its phenotypes, it has been used as a genetic marker in studies of associations with infectious and non-infectious diseases $[5,6]$. The ABO is the most clinically important antigen classification system to date. Its recognition is central to the practice of transfusion medicine, because of the immediate recognition and rejection of major incompatible non-self-cells.

Since the second World War, blood and blood component transfusion have been used to correct severe anaemia, deficiency of plasma clotting factors, thrombocytopenia, immunodeficiency states, hypoalbuminaemia and problems related to electrolytes $[7,8]$. Transfusion of compatible blood at least for $\mathrm{ABO}$ and $\mathrm{Rh}$ antigens reduces transfusion reactions in recipients. The $\mathrm{ABO}$ and $\mathrm{Rh}$ blood groups are 
also useful in clinical studies, population genetic studies and researching population migration patterns as well as resolving certain medicolegal issues particularly of disputed paternity cases [9]. Therefore, knowledge of the ABO and $\mathrm{Rh}$ blood group distribution in specific population has paramount importance in the context of transfusion medicine. Many previous studies in sub-Saharan Africa reported that blood group $\mathrm{O}$ and $\mathrm{Rh}$ positive are the most frequent $\mathrm{ABO}$ and $\mathrm{Rh}$ blood groups respectively but the proportion varies by location [10-13].

An antigen is any substance to which the immune system can respond. For example, components of the bacterial cell wall can trigger severe and immediate attacks by neutrophils. If the immune system encounters an antigen that is not found on the body's own cells, it will launch an attack against that antigen. Conversely, antigens that are found on the body's own cells are known as "self-antigens", and the immune system does not normally attack these. The membrane of each red blood cell contains millions of antigens that are ignored by the immune system. However, when patients receive blood transfusions, their immune systems will attack any donor red blood cells that contain antigens that differ from their self-antigens. Therefore, ensuring that the antigens of transfused red blood cells match those of the patient's red blood cells is essential for a safe blood transfusion [14].

Blood group antigens are either sugars or proteins, and they are attached to various components in the red blood cell membrane. The antigens of the ABO blood group are sugars. They are produced by a series of reactions in which enzymes catalyze the transfer of sugar units. A person's DNA determines the type of enzymes they have, and, therefore, the type of sugar antigens that end up on their red blood cells. In contrast, the antigens of the $\mathrm{Rh}$ blood group are proteins. A person's DNA holds the information for producing the protein antigens. The $\mathrm{RhD}$ gene encodes the $\mathrm{D}$ antigen, which is a large protein on the red blood cell membrane. Some people have a version of the gene that does not produce $\mathrm{D}$ antigen, and therefore the $\mathrm{RhD}$ protein is absent from their red blood cells. If this protein is present on a particular blood type, that blood type is called positive then if absent, it is called negative [15].

Malaria (which is caused by Plasmodium species transmitted by anopheles mosquitoes) is the second leading disease following Acquired Immunodeficiency SyndromeAIDS [16] associated with high morbidity and mortality through anaemia, cerebral complications and other mechanisms [16].

Despite the high morbidity and mortality, certain individuals living in malaria endemic regions appear relatively protected compared to those who suffer frequent severe malaria attacks. Resistance to malaria infection is dependent on the development of an immune response by the host and to a varying extent, a certain innate characteristic possessing protective value against infection [17]. These factors include Sickle cell trait (HbAS) and Sickle cell disease $-\mathrm{HbSS}$ [18], ABO blood types [19] and the level of G-6-P- dehydrogenase [20].
Both $\mathrm{ABO}$ and $\mathrm{Rh}$ blood groups have attracted enormous attention regarding their association with genetic and infectious diseases [21]. Previous studies on cancer and tumor patients [22], heart diseases [23], parasitic and viral infections [24] indicated associations of $\mathrm{ABO}$ and $\mathrm{Rh}$ blood groups. In particular, The $\mathrm{ABO}$ antigens regulate cellular activities suggesting their impact on determining susceptibility and severity of certain diseases [25]. It has been more than four decades since association of $\mathrm{ABO}$ blood group and malaria was suggested. There is also a hypothesis that Plasmodium falciparum malaria has shaped the distribution of ABO blood groups in humans [26].

It is thought that an understanding of the nature of relationship (if any) between $\mathrm{ABO}$ blood groups and malaria parasitaemia should provide an invaluable window in the scourge and that studies of malaria parasitaemia from that stand point in populations of malaria endemic regions will be helpful in elucidating any such relationship [12].

A high percentage of severe malaria cases have been reported among blood group A individuals [27, 28]. Furthermore, Migot-Nabias [29] and Pathirana et al. [30] observed low paraitaemia and uncomplicated malaria cases among blood group $\mathrm{O}$ individuals.Similarly, a significant advantage of Plasmodium falciparum with ABO blood groups with respect to group $\mathrm{O}$ has been reported by some authors $[31,32]$. Other studies have shown high frequency of malaria episodes among blood group A individuals as compared with other blood group individuals [33]. Akhigbe et al. [34] reported that blood group $\mathrm{AB}$ persons had the lowest malaria attack while blood group A persons had the highest attack.

Studies to investigate any possible association between ABO blood group system and some disease conditions have been carried out by some authors [35-40]. Some of these studies reported significant associations thereby suggesting that $\mathrm{ABO}$ blood groups have an impact on the infection status of the individuals possessing a particular $\mathrm{ABO}$ blood group [37, 38, 39, 40].

The absence of significant association between $P$. falciparum prevalence and $\mathrm{ABO}$ antigens has also been reported by some other studies [16, 41, 42, 32]. Other authors are less equivocal in relating malaria parasitaemia to $\mathrm{ABO}$ blood group [43, 44]. Otajevwo [9] in a study associating malaria parasitaemia with $\mathrm{ABO}$ blood types among residents of Warri, Nigeria, reported that $6.9 \%, 19.0 \%, 20.7 \%$ and $53.3 \%$ of a total of 174 whole blood samples processed belonged to blood types $\mathrm{AB}, \mathrm{B}, \mathrm{A}$ and $\mathrm{O}$ respectively and $138(79.3 \%)$ of total sample size were infected with malaria parasites of which $P$. falciparum was the predominant species. In the report, the highest malaria parasite load was observed among group $\mathrm{O}(52.2 \%)$ individuals while the least was noticed among blood group $\mathrm{AB}(8.7 \%)$ individuals. Malaria parasitaemia was higher among the males $(83.3 \%)$ than females (75.0\%). Otajevwo [45] also reported ABO blood types among students of Igbinedion University, Okada, Nigeria of which out of 104 samples analyzed, 44(3.9\%), $16(15.4 \%), 32(30.8 \%)$ and $52(50.0 \%)$ students occurred in $\mathrm{AB}, \mathrm{A}, \mathrm{B}$ and $\mathrm{O}$ groups respectively. On the whole, 
$80(76.8 \%)$ of total samples processed, were positive for malaria parasitaemia.

Nkuo-Akenji [46] reported that blood group O individuals maybe more susceptible to malaria attack. A study conducted in Edo State University, Nigeria reported that blood groups O and $\mathrm{B}$ male individuals were the most and least susceptible to malaria attack respectively [19]. In a study conducted on inhabitants of Odakpu, Anambra State,Ilozumba and Uzozie [12] reported $\mathrm{ABO}$ blood group prevalence of $2.63 \%$, $12.05 \%, 21.1 \%$ and $63.8 \%$ for groups $\mathrm{AB}, \mathrm{B}, \mathrm{A}$, and $\mathrm{O}$ respectively. Zerihun et al. [47] reported that $\mathrm{A}, \mathrm{B}$ and $\mathrm{AB}$ blood group individuals are more vulnerable to $P$. falciparum infection compared to blood group $\mathrm{O}$ individuals in a study they carried among 269 febrile Ethiopian out patients who visited a health care.

Despite the above researches, a consensus on possible association between $\mathrm{ABO}$ blood group genes and malaria infection is still lacking [48]. This might be due to limited data or unreported data on the cell antigens [46], peculiar demographic distributions and characteristics of study areas [41]. A definite statement on the apparent trend can be made therefore, if results of more studies on ABO blood groups associated with malaria infection in different parts of Nigeria and other neighboring countries are made available and accessible [12]. No known study has been done involving students of Babcock University of their ABO blood types were linked or associated with Plasmodium falciparum malaria infection and hence, the aim of this work is $\mathrm{ABO}$ blood variants of selected Babcock University students and their association with malaria infection with specific objectives as listed below:

1. ABO blood phenotypes and rhesus frequency distribution among students recruited for study with respect to sex.

2. Age distribution of ABO blood types of Babcock University students recruited for the study

3. Sex distribution of Plasmodium falciparum malaria infection among Babcock University students recruited for the study.

4. Association of severe and non-severe forms of Plasmodium falciparum malaria infection with $\mathrm{ABO}$ blood phenotypes of students recruited

\section{Materials and Methods}

\subsection{Ethical Clearance}

Ethical clearance was obtained from Babcock University Health Research Ethics Committee for the approval of the research proposal and other related materials after the necessary reviews and corrections. The students who volunteered their blood samples signed informed consent forms to show their approval before blood samples were collected from them.

\subsection{Criteria for Selection of Subjects}

Both symptomatic and asymptomatic subjects (students) were used for the study. Symptomatic subjects were those that were positive for malaria parasite test and showed obvious signs of illness. Asymptomatic subjects were those who were apparently healthy although positive for malaria parasite test. For clarity, symptomatic subjects were grouped as those having severe malaria parasitaemia while asymptomatic subjects were those with non-severe malaria parasitaemia.

\subsection{Sampling}

Five milliliters $(5 \mathrm{ml})$ of venous blood was collected from each of one hundred and eighty three students made up of 93 $(50.8 \%)$ male and $90(49.2 \%)$ female students of Babcock University Ilishan Remo, Ogun State randomly selected across various departments. Blood collection was done by venous puncture. With the aid of a tourniquet, a prominent vein was located on the fore arm and the vein area was sterilized with $70 \%$ ethanol soaked cotton wool swabs. Using sterile $5 \mathrm{ml}$ syringe and needle, five milliliters $(5 \mathrm{ml})$ of venous blood was withdrawn from subjects into appropriately labeled ethylene diamine tetra-acetic acid (ETDA) blood containers. All containers were properly mixed by standard method in order to sufficiently mix the anticoagulant with the blood to stop coagulation from taking place. Blood samples were collected by a qualified and licensed Medical Laboratory Scientist who is a Babcock University staff. Sterile Hand gloves and knee length laboratory coats were worn all through blood collection and disposal period. Specimens were properly labeled, packaged and kept in a functional refrigerator before and after use.

\subsection{Duration/Venue of Study}

This study was carried out between when ethical clearance was obtained and end of March, 2016. The venue of the research was the Microbiology laboratory of Bioscience Department of Babcock University, Ogun State, Nigeria.

\subsection{Malaria parasite Staining}

Thick blood films were made on grease free microscope slides (after appropriate labeling) and allowed to air dry on laboratory working bench. Slides were arranged on a staining rack and flooded with Field Stain A (containing methylene blue) and Field Stain B (containing eosin) analytical grade (Glanson Chemicals, Nigeria). Staining was done according to standard methods [49](Brooks et al., 2004). The plus system was used for the determination of parasite density [50](WHO, 1990). Only positive results were recorded and used for $\mathrm{ABO}$ group typing.

\subsection{Typing Blood Samples for Blood Group Antigens}

The ABO blood typing of each subject was determined using cell grouping Antisera according to methods described by Rosenfield [51] and Cheesbrough [52]. Monoclonal Antisera A, B and D (Agape Diagnostics, Ltd, India) were used. Antisera A and B were for ABO blood typing while Antiserum D was for Rhesus factor typing. 


\subsection{Statistical Analysis of Data}

Chi square $\left(\mathrm{x}^{2}\right)$ analysis using test of independence of two characters or associations using a $4 \times 3$ contingency table at $95 \%$ confidence interval was used. The software used was the statistical package for social sciences (SPSS) version 17.0. Confidence interval at $95 \%$ (0.05) was calculated using mean \pm $0.05 \mathrm{~S}_{\mathrm{X}}$ with degree of freedom calculated using (r-1) (c-1).

\section{Results}

The data on $\mathrm{ABO}$ blood groups and Rhesus factor frequency distribution among Babcock University students are shown in Table 1. A total of 183 whole blood samples obtained from 93 $(50.8 \%)$ and $90(49.2 \%)$ male and female students respectively were processed for $\mathrm{ABO}$ blood types. Out of this sample size, whereas $92(54.4 \%)$ and $77(45.6 \%)$ students were rhesus positive males and females respectively, 1 (7.1\%) and 13 (92.9\%) students were rhesus negative males and females respectively. On the whole, a total of $169(92.3 \%)$ and $14(7.7 \%)$ students were rhesus positive and negative respectively.

A total of $54(58.1 \%), 24(25.8 \%), 12(12.9 \%)$ and 3 (3.2\%) male students belonged to groups $\mathrm{O}, \mathrm{A}, \mathrm{B}$ and $\mathrm{AB}$ blood types respectively while a total of $56(62.2 \%), 17$ $(18.9 \%), 14(15.6 \%)$ and $3(3.3 \%)$ female students were grouped into $\mathrm{O}, \mathrm{B}, \mathrm{A}$ and $\mathrm{AB}$ blood types respectively in that descending order. This showed that the most predominant blood group among Babcock University students is group $\mathrm{O}$ while the least is AB type. In the male students' population, the next highest occurring blood group was group A while it was group B in the female students' population.

Table 1. Phenotypic ABO blood types and rhesus frequency distribution among students recruited for study with respect to sex.

\begin{tabular}{lllll}
\hline $\begin{array}{l}\text { ABO blood } \\
\text { types }\end{array}$ & Sex & $\begin{array}{l}\text { Rhesus } \\
\text { positive (\%) }\end{array}$ & $\begin{array}{l}\text { Rhesus } \\
\text { Negative (\%) }\end{array}$ & Total \\
\hline A & M & $24(26.1)$ & $0(0.0)$ & $24(25.8)$ \\
& F & $11(14.3)$ & $3(23.1)$ & $14(15.6)$ \\
B & M & $12(13.0)$ & $0(0.0)$ & $12(12.9)$ \\
& F & $12(15.6)$ & $5(38.5)$ & $17(18.9)$ \\
AB & M & $3(3.3)$ & $0(0.0)$ & $3(3.2)$ \\
& F & $3(3.9)$ & $0(0.0)$ & $3(3.3)$ \\
O & M & $53(57.6)$ & $1(100)$ & $54(58.1)$ \\
& F & $51(66.2)$ & $5(38.5)$ & $56(62.2)$ \\
Total & $\mathrm{M}$ & $92(54.4)$ & $1(7.1)$ & $93(50.8)$ \\
Overall total & F & $77(45.6)$ & $13(92.9)$ & $90(49.2)$ \\
\hline
\end{tabular}

The results of the age distribution of ABO blood types of Babcock University students recruited for the study are shown in Table 2. The subjects were grouped into 17-20, 21 24 and 25-30 age brackets of which 135 (73.8\%), 36 (19.7\%) and $12(6.5 \%)$ students belonged to each group respectively. This suggested that the highest of subjects involved in the study belonged to the $17-20 \mathrm{yr}$ age bracket with an average age of $19 y$ rs. This was distantly followed by 21-24 age bracket with an average age of 23 yrs.

Table 2 clearly shows in decreasing order, that 110 $(60.1 \%), 38(20.8 \%), 29(15.9 \%)$ and $6(3.3 \%)$ students belonged to blood types $\mathrm{O}, \mathrm{A}, \mathrm{B}$ and $\mathrm{AB}$ respectively indicating that the highest and next highest occurring blood types in the studied population were groups $\mathrm{O}$ and $\mathrm{A}$ while the least occurring was clearly AB group.

In decreasing order, $77(57.0 \%), 21(58.3 \%)$ and 12 (100.0\%) group O students were of 17-20, 21-24 and 25-30yr age brackets respectively. Twenty nine (21.5\%), 9 (25.0\%) and $0.0 \%$ group A students belonged to the same age groups respectively. Similarly, $23(17.0 \%), 6(16.7 \%)$ and $0.0 \%$ blood group B students were of the same age brackets respectively. Vertically, the distribution of ABO blood types in the 17-20 age group included $77(57.0 \%), 29(21.5 \%), 23$ $(17.0 \%)$ and $6(4.4 \%)$ belonging to types $\mathrm{O}, \mathrm{A}, \mathrm{B}$ and $\mathrm{AB}$ respectively. In the 21-24 age group, $21(58.3 \%), 9(25.0 \%)$, $6(16.7 \%)$ and $0.0 \%$ students were of $\mathrm{O}, \mathrm{A}, \mathrm{B}$ and $\mathrm{AB}$ groups respectively and lastly, in the 25-30 bracket, only 12 $(100.0 \%)$ students were of group O blood type (Table 2).

Table 2. Age distribution of ABO blood types of Babcock University students recruited for the study.

\begin{tabular}{lllll}
\hline ABO Blood Types & $\begin{array}{l}\mathbf{1 7 - 2 0 y r} \\
(\%)\end{array}$ & $\begin{array}{l}\mathbf{2 1 - 2 4 y r} \\
\mathbf{( \% )}\end{array}$ & $\begin{array}{l}\mathbf{2 5 - 3 0 y r} \\
(\mathbf{\%})\end{array}$ & $\begin{array}{l}\text { Total } \\
(\%)\end{array}$ \\
\hline A & $29(21.5)$ & $9(25.0)$ & $0(0.0)$ & $38(20.8)$ \\
B & $23(17.0)$ & $6(16.7)$ & $0(0.0)$ & $29(15.9)$ \\
AB & $6(4.4)$ & $0(0.0)$ & $0(0.0)$ & $6(3.3)$ \\
O & $77(57.0)$ & $21(58.3)$ & $12(100.0)$ & $110(60.1)$ \\
Total & $135(73.8)$ & $36(19.7)$ & $12(6.5)$ & $183(100.0)$ \\
\hline
\end{tabular}

The distribution of malaria parasitaemia among Babcock University students based on their sex is shown in Table 3. A total of 183 blood samples obtained from 93(50.8\%) and $90(49.2 \%)$ male and female students respectively were processed to determine their malaria parasite status. Out of this sample size, $126(68.9 \%)$ students were infected or positive for various asexual forms of plasmodium falciparum in their peripheral blood circulation of which 66(52.4\%) and 60(47.6\%) were infected male and female students respectively. Malaria parasite load in terms of $(+),(++),(+++)$ and $(++++)$ semiquantitatively estimated were all grouped as MP positive. A total of $57(31.1 \%)$ students made up of $27(47.4 \%)$ and $30(52.6 \%)$ male and female students respectively were un-infected or negative for malaria parasites in their blood system. Chi square $\left(\mathrm{X}^{2}\right)$ analysis carried out on data showed that sex (gender) was significantly associated with malaria parasitaemia at both $95 \%$ and $99 \%$ confidence intervals $\left(\mathrm{X}_{0.05,1}^{2}=3.841, \mathrm{X}_{0.01,1}^{2}=6.635\right.$, Cal. $\mathrm{X}^{2}=28.797$ and hence, $\left.\mathrm{P}<0.05, \mathrm{P}<0.01\right)$.

Table 3. Sex distribution of malaria parasitaemia among Babcock University students recruited for study.

\begin{tabular}{llll}
\hline \multirow{4}{*}{ Sex } & \multicolumn{3}{l}{ Malaria Parasite Status } \\
\cline { 2 - 4 } & $\begin{array}{l}\text { Positive malaria } \\
\text { parasite Test (\%) }\end{array}$ & $\begin{array}{l}\text { Negative malaria } \\
\text { parasite test (\%) }\end{array}$ & \multirow{2}{*}{ TOTAL } \\
\hline Males & $66(52.4)$ & $27(47.4)$ & $93(50.8)$ \\
Females & $60(47.6)$ & $30(52.6)$ & $90(49.2)$ \\
Total & $126(68.9)$ & $57(31.1)$ & $183(100.0)$ \\
\hline
\end{tabular}

$\mathrm{df}=(\mathrm{r}-1)(\mathrm{c}-1)=1 \times 1=1$

Critical (P-value) of $\mathrm{X}^{2}{ }_{0.05,1}=3.841$

Critical (P-value) of $\mathrm{X}^{2}{ }_{0.01,1}=6.635$

Calculated $\mathrm{X}^{2}=25.253$

At $95 \%, 99 \%$ C.I, $\mathrm{P}<0.05, \mathrm{P}<0.01)$. 
Data on severe and non-severe malaria parasitaemia among ABO blood types of randomly selected Babcock University students are shown in Tables 4 and 5 respectively. Infected students whose stained thick films showed the presence of P. falciparum asexual forms such as schizonts, merozoites and who showed obvious signs of malaria infection were grouped as suffering from severe malaria parasitaemia. Out of a total sample size of 183 , a total of $126(68.9 \%)$ students were infected with malaria parasites out of which $47(37.3 \%)$ and $79(62.7 \%)$ had severe and non-severe forms of malaria infection respectively. Blood type $\mathrm{O}$ recorded the second to the highest rate of severe malaria infection $(70.6 \%)$ and the third highest rate of non-severe malaria infection $(65.8 \%)$. The highest rates of severe and non-severe malaria infection which were $85 \%$ and $83.3 \%$ respectively were recorded by blood group A students. Whereas blood group A students recorded the second highest rate of severe malaria infection (70.6\%), they recorded the third highest rate of non-severe malaria infection of $65.8 \%$. Group $\mathrm{AB}$ students however, recorded the second highest rate of non-severe malaria parasitaemia. The lowest rate of severe and non-severe forms of malaria infection was recorded by group B students. A total of 19(28.8\%) and $38(32.5 \%)$ students across all blood types were un-infected with severe and non-severe forms of $\mathrm{P}$. falciparum malaria parasites respectively. Statistically, there was a significant association of the blood types with severe form of P.falciparum infection $\left(\mathrm{X}^{2} \mathrm{df}(3)_{0.05}=7.815, \mathrm{X}^{2} \mathrm{df}(3)_{0.01}=\right.$ 11.350, Cal. $\left.\mathrm{X}^{2}=284.601, \mathrm{P}<0.05, \mathrm{P}<0.01\right)$ and there was also a significant association of the blood groups with non-severe form of P.falciparum infection $\left(\mathrm{X}^{2} \mathrm{df}(3)_{0.05}=7.815, \mathrm{X}^{2} \mathrm{df}(3)\right.$ ${ }_{0.01}=11.350$, Cal. $\mathrm{X}^{2}=230.768$ and hence, $\mathrm{P}<0.05, \mathrm{P}<0.01$ )

Table 4. Distribution of severe malaria parasitaemia among ABO blood types of Babcock University students recruited for study.

\begin{tabular}{|c|c|c|c|c|c|}
\hline \multirow{2}{*}{$\begin{array}{l}\text { Malaria } \\
\text { Status }\end{array}$} & \multicolumn{4}{|c|}{ ABO Blood Types } & \multirow{2}{*}{ TOTAL } \\
\hline & $\mathbf{A}$ & B & $\mathbf{A B}$ & $\mathbf{O}$ & \\
\hline Infected & $17(85.0)$ & $5(50.0)$ & $1(50.0)$ & $24(70.6)$ & $47(71.2)$ \\
\hline Un-infected & $3(15.0)$ & $5(50.0)$ & $1(50.0)$ & $10(29.4)$ & $19(28.8)$ \\
\hline Total & $20(30.3)$ & $10(15.2)$ & $2(3.0)$ & $34(51.5)$ & $66(36.1)$ \\
\hline
\end{tabular}

$\mathrm{df}=(\mathrm{r}-1)(\mathrm{c}-1)=(2-1)(4-1)=1 \times 3=3$

Critical (P-value) of $\mathrm{X}^{2}{ }_{0.05,3}=7.815$

$\mathrm{X}_{0.01,3}^{2}=11.350$

Calculated $\mathrm{X}^{2}=284.601$

At $95 \%$ C.I, $\mathrm{P}<0.05$

At $99 \%$ C.I, $\mathrm{P}<0.01$

Table 5. Distribution of non-severe malaria parasitaemia among ABO blood types of Babcock University students recruited for study.

\begin{tabular}{|c|c|c|c|c|c|}
\hline \multirow{2}{*}{$\begin{array}{l}\text { Malaria } \\
\text { Status }\end{array}$} & \multicolumn{4}{|c|}{ ABO Blood Types } & \multirow{2}{*}{ TOTAL } \\
\hline & $\mathbf{A}$ & B & $\mathbf{A B}$ & $\mathbf{O}$ & \\
\hline Infected & $15(83.3)$ & $11(57.9)$ & $3(75.0)$ & $50(65.8)$ & $79(67.5)$ \\
\hline Un-infected & $3(16.7)$ & $8(42.1)$ & $1(25.0)$ & $26(34.2)$ & $38(32.5)$ \\
\hline Total & $18(15.4)$ & $19(16.2)$ & $4(3.4)$ & $76(65.0)$ & $117(63.9)$ \\
\hline
\end{tabular}

$\mathrm{df}=(\mathrm{r}-1)(\mathrm{c}-1)=(2-1)(4-1)=1 \times 3=3$

Critical (P-value) of $\mathrm{X}^{2}{ }_{0.05,3}=7.815$

$\mathrm{X}^{2}{ }_{0.01,3}=11.350$

Calculated $X^{2}=230.768$

At $95 \%$ C.I, $\mathrm{P}<0.05$

At $99 \%$ C.I, $\mathrm{P}<0.01$

\section{Discussion}

This study was geared towards determining the ABO blood types/rhesus factor statuses of a sampled population of Babcock University students as well as probing into any possible link of these ABO phenotypes with Plasmodium falciparum malaria infection. This has immense significance in terms of transfusion medicine and malaria control [53]. This is because transfusion of compatible blood groups is useful in clinical studies, population genetic studies, researching population migration patterns and resolving certain medicolegal issues especially relating to disputed paternity cases [54]. Rhesus grouping is based on the presence or absence of the $\mathrm{D}$ antigen on red blood cells $[10,55]$.

In this study, $169(92.3 \%)$ and $14(7.7 \%)$ students were rhesus positive and rhesus negative respectively of which 92 (54.4\%) and 77(45.6\%) male students respectively were rhesus positive and of which $1(7.1 \%)$ and $13(92.9 \%)$ male and female students respectively were rhesus negative. This revealed that rhesus positive factor occurred by over $70 \%$ more than rhesus negative factor. This result is supported by the report of some previous authors $[56,57,45,58]$. The overall rhesus negative frequency of $7.7 \%$ obtained in this study appears small compared to the sample size but however, has far reaching medical implication in the area of childbirth and stillbirth which may arise from haemolytic disease of newborn (HDN) or erythroblastosis fetalis which occur only in rhesus negative pregnant women at second delivery. This rhesus negative frequency rate when compared to $5.8 \%$ recorded by Otajevwo and Igoniwari [58] suggests that rhesus negative factor is occurring in increasing frequencies from population to population and hence, there is need for relevant healthcare providers as well as the Ministry of Health to track down people (women) with this factor through compulsory blood typing tests especially during prenatal hospital visits. Many previous studies have however reported that rhesus positive population are much more frequent compared to that of rhesus negative although in varying proportions based on varied locations $[59,9,11,12]$.

The findings in this study also show that the frequency occurrence of the $\mathrm{ABO}$ blood types were $60.1 \%, 20.8 \%$, $15.9 \%$ and $3.3 \%$ for groups $\mathrm{O}, \mathrm{A}, \mathrm{B}$ and $\mathrm{AB}$ respectively (Table 2). This further validates the reports of previous authors which stated that blood groups $\mathrm{O}$ and $\mathrm{AB}$ are the most and least prevalent in any population $[13,38,45,47$, $60-66,34,12]$. These findings are not however consistent with an earlier report which stated that groups $\mathrm{O}$ and $\mathrm{A}$ are the highest and least occurring groups [19]. These differences may be due to ethnic, racial and geographical disparities inherent in various populations.

$\mathrm{ABO}$ blood types as well as rhesus blood types have attracted enormous attention regarding their association with genetic and infectious diseases [55]. Previous studies on patients of cancer and tumor [67], heart disease [58], parasitic and viral infections [22] indicated associations of $\mathrm{ABO}$ and rhesus blood groups. In particular, the $\mathrm{ABO}$ antigens regulate cellular activities suggesting their impact 
on determining susceptibility and severity of certain diseases [68]. In this study also, out of a total sample size of 183, $126(68.9 \%)$ students were infected with P.falciparum malaria parasites of which $47(37.3 \%)$ and $79(62.7 \%)$ had severe and non-severe forms of Plasmodium falciparum malaria infection respectively. This parasitaemia rate of $68.9 \%$ is significant and shows that Babcock University campus environment maybe endemic for malaria. This calls for the necessary or relevant University authorities to step up efforts to control the scourge. Students' hostel environments, hostel rooms and indeed, the entire University environment should be kept clean.

The parasitaemia rate obtained in this study however, appears to be low compared to $93.4 \%$ obtained in Odoakpu, Onitsha South [12] and 77.4\% obtained in Owerri [69]. Parasitaemia rate obtained in this study (68.9\%) appears high however when compared with prevalence rate of $66.9 \%$, $58.3 \%, 43.2 \%, 10.0 \%$ and $6.0 \%$ obtained respectively for subjects in Ogbomosho [34]., children in Awka [70], coastal dwellers in Lagos [71], blood donors in Ibadan [72] and blood donors in Maiduguri [73]. These differences in parasitaemia rates may suggest the existence of regional differences in malaria infection rates in Nigeria with Western, Midwestern and Eastern areas (represented by IIishan Remo, Ogbomosho, Onitsha and Owerri) ranking highest in prevalence rating and the northern areas (represented by Maiduguri) occupying the lowest position while Lagos and Ibadan take a middle position. More studies however, should be done by other authors in other parts of Nigeria before a more definite statement on the apparent trends could be made.

At $95 \%$ and $99 \%$ confidence intervals, chi square statistical analysis carried out on data showed that male students were significantly more infected than the females. This finding is supported by the reports of some previous studies which stated that males were more vulnerable to malaria infection than females [74, 12, 69]. Finding is however, inconsistent with the report of some workers [34]. According to Portilo and Sullivan [75], genetic factors could play a role by endowing females with immune-regulatory potentials to cope better with some diseases.

In this study, attempt was made to link two forms of malaria (severe and non-severe) with ABO blood types. According to Beng-Ong and Hill [76], pathogenesis of severe malaria is due to the presence of of asexual forms such as schizonts, merozoites and trophozoites of P.falciparum in a stained thick blood film under microscope view with patient showing signs of malaria infection. The frequency occurrence of severe malaria therefore among the blood types were $85.0 \%, 70.6 \%, 50.0 \%$ and $50.0 \%$ for groups $\mathrm{A}, \mathrm{O}, \mathrm{B}$ and $\mathrm{AB}$ respectively (Table 4). This implied that group $\mathrm{A}$ students were most susceptible to severe malaria infection followed by group $\mathrm{O}$ subjects while the least vulnerable were groups $\mathrm{B}$ or $\mathrm{AB}$. The finding by some authors stating that blood group $\mathrm{O}$ seems to confer a certain degree of protection against severe cases of malaria disease does not agree with the present finding in that regard [77, 78, 29, 79]. Also, according to Athreya and Coriell [24], malaria is a disease for which an association with $\mathrm{ABO}$ blood group distribution seems to exist and which may have played an important role in shaping the prevalence in favour of group $\mathrm{O}$.

The finding in this study linking group A individuals as most prone to malaria infection does not agree with the reports of Singh et al. [80] which stated that group O subjects are more susceptible to malaria than other $\mathrm{ABO}$ blood groups. Other authors reported that group $\mathrm{AB}$ individuals were more affected than other groups by malaria $[12,81]$.

With respect to non-severe form of malaria and its association with the ABO blood types, the ABO blood type frequencies of non-severe infection were $83.3 \%, 75.0 \%$, $65.8 \%$ and $57.9 \%$ with regard to blood types $\mathrm{A}, \mathrm{AB}, \mathrm{O}$ and $\mathrm{B}$ respectively. It is obvious that group A subjects (as in the case of severe malaria) were most vulnerable to non-severe form of P.falciparum malaria infection. Surprisingly, group $\mathrm{AB}$ subjects were the second most susceptible to non-severe form of malaria. Clearly, group B students were least vulnerable to severe and non-severe forms of P.falciparum malaria infection (Tables 4 and 5).

The report of a previous study stated that group O subjects were most prone to severe and non-severe forms of malaria and this contradicts findings in the present study. This study also shows that group B individuals were least prone to malaria and this is supported however by the report of Otajevwo and Igoniwari [57]. Also, in this study, group $\mathrm{O}$ individuals recorded the second highest and third highest frequencies of severe and non-severe forms of malaria infection respectively and this negates the finding by some authors stating that blood group $\mathrm{O}$ seems to confer a certain degree of protection against severe cases of malaria disease $[77,78]$.

The finding in this work that group $\mathrm{O}$ subjects are not most susceptible to malaria is not supported by the reports of some earlier authors [82, 29, 79, 34, 83, 84]. Present finding also disagrees with the reports of some previous authors which stated that blood group $\mathrm{O}$ individuals usually have low malaria attack because parasitized red blood cells have stronger tendency to form rosettes with un-infected erythrocytes of the $\mathrm{A}, \mathrm{B}$ and $\mathrm{AB}$ blood groups than with those of blood group $\mathrm{O}[85,86,87,88]$.

Both $\mathrm{ABO}$ and rhesus blood groups have attracted enormous attention regarding their association with genetic and infectious diseases [89]. Previous studies on patients of cancer and tumor [67], heart diseases [58], parasitic and viral infections [22]. indicated associations of $\mathrm{ABO}$ and rhesus blood groups. In particular, the $\mathrm{ABO}$ antigens regulate cellular activities suggesting their impact on determining susceptibility and severity of certain diseases 23]. There is a hypothesis that Plasmodium falciparum malaria has shaped the distribution of ABO blood groups in humans [24]. The pathophysiological plausibility of an interaction between malaria parasite and red blood cells as well as the potential role erythrocyte surface antigens may play in cytoadhesion of infected erythrocytes and parasite invasion may give credence to a possible association between $\mathrm{ABO}$ blood types 
and malaria infection [82].

Numerous studies have been carried out to determine any possible association between $\mathrm{ABO}$ blood groups and malaria [16] and most findings from such study have been contradictory [16]. Herrera et al. [41] reported that there was no association between $\mathrm{ABO}$ blood types and malaria parasitaemia and that the controversial association of these variables previously found in other populations may be due to their peculiar demographic distributions and characteristics.

Chi square statistical analysis was carried out to associate severe and non-severe malaria parasitaemia with $\mathrm{ABO}$ blood groups. In the case of severe malaria infection and $\mathrm{ABO}$ blood types, there was a significant association existing between severe malaria blood infection and ABO blood types particularly with respect to group A and there was also a significant association between non-severe malaria infection and $\mathrm{ABO}$ types with emphasis on group $\mathrm{A}$ also. This established association between both variables in this study is in disagreement with some earlier studies and their reports which recorded no association $[16,46,36,89,90,13,11$, 66]. Present finding however, is supported by [47] who reported significant association between variables.

Many other co-existing factors made the study of relationship between malaria and $\mathrm{ABO}$ blood types difficult with conflicting findings reported. It is possible that complexity of the interaction between the parasites and host immune responses as well as the impact of other RBC polymorphisms may be responsible for such differences [25, 19, 91-94].

\section{Conclusion}

This work has revealed that there are more rhesus positive male Babcock University students than females but on the other hand, there are more rhesus negative female than male students. Rhesus negative frequency of $7.7 \%$ is high and shows a steady rise in its occurrence in populations. $A B O$ blood types $\mathrm{O}$ and $\mathrm{AB}$ recorded the highest and lowest occurrence frequencies respectively. More male students than female students were significantly associated with malaria parasitaemia of which group A individuals were significantly associated with both severe and non-severe forms of $\mathrm{P}$. falciparum malaria infection compared to the other groups. Hence, severe and non-severe forms of malaria were significantly associated with $\mathrm{ABO}$ blood types. Although findings suggested that group A subjects were most prone to malaria attack, malaria parasites don't discriminate between blood types and hence, all ABO blood groups are equally at risk and therefore, available prophylactic and therapeutic anti-malaria strategies by relevant health agencies should take into account persons of all groups. Rhesus negative frequency of $7.7 \%$ in female students in this study shows a steady rise compared to previous studies and this calls for the attention of prenatal and ante-natal Healthcare providers in order to prevent HDN from occurring.

\section{References}

[1] Garratty, G. (2000). Blood groups and disease: a historical perspective. Transfus Med Rev, 14: 291-301.

[2] Rahman, M and Lodhi, Y. (2004). Prospects and future of conservative management of beta thalassemia major in a developing country. Pak. Journ. Med Sci. 20(2): 105-112.

[3] Dacie, J. V. and Lewis, S. M. (2001). In: Lewis, S. M., Bain, B. J., Bates, I., Editors. (9th ed). London: Churchill Livingstone, Harcourt Publishers Limited. Practical Hematology, 444-451.

[4] Giri, C., Ochieng, E., Tieszen, L. L and Duke, N. (2010). Status and distribution of mangrove forests of the World using earth observation satellite data. Global Ecology and Biogeography. 20(1): 154-159.

[5] Mourant, A. E., Kopec, A C. and Domaniewska-Sobczak, K. (1976). The distribution of the human blood groups and other polymorphisms, London: Oxford University Press.

[6] Mourant, A. E., Kopec, A. C. and Domaniewska-Sobczak, K. (1978). Blood groups and diseases: a study of associations of diseases with blood groups and other polymorphisms, London: Oxford University Press.

[7] Talib, V. N., Aggarwall, M. P and Khuarana, S. R. (2004). Valliliv in hepatic disorders with special reference to serum hepatitis. Curr. Med. Prac. 32(8): 197-202.

[8] Epid, T. T., Nwani, C. D. and Ugorji, N. P. (2008). Prevalence of malaria in blood donors in. Abakaliki Metropolis, Nigeria. Sci Res Essays, 3: 162-164.

[9] Otajevwo, FD. (1997). ABO Blood group association with malaria parasitaemia among residents in Warri Delta State. Journal of Science and Technology. 4: 32-36.

[10] Yamamoto, F. I., McNeil, P. D and Hakomori S. I. (1995). "Genomic organization of human histo-blood group $\mathrm{ABO}$ genes" Glycobiology. 5(1): 51-58.

[11] Sirina, M. and Clement, O. (2013). The prevalence of malaria parasitaemia and predisposition of $\mathrm{ABO}$ blood groups to Plasmodium falciparum malaria among blood donors of Ghanaian Hospital. AU Journal of Technology, 16 (4); 255266.

[12] Ilozumba, H. C and Uzozie, C. R. (2009). Prevalence of malaria parasitaemia and its association with $\mathrm{ABO}$ blood group in Odoakpu Area of Onitsha South Local Government Area; Anambra State Nigeria. Nigerian Annals of Natural Science, 8(2): 1-8.

[13] Oladeinnede, B. H; Omoregie, R; olley, M; and Anunibe, J. A. (2014). Urinary tract infection in a rural community of Nigeria. North Amer. Journ. Med. Sci. 3(2): 75-77.

[14] Daniels, G. L., Fletcher, A., Garratty, G., Henry, S., Jorgensen, J., Judd, W. J., Levene, C., Lomas-Francis, C., Moulds, J. J., Moulds, J. M., Moulds, M., Overbeeke, M., Reid, M. E., Rouger, P., Scott, M., Sistonen, P., Smart, E., Tani, Y., Wendel, S. and Zelinski, T. (2004). Blood group terminology: from the International Society of Blood Transfusion committee on terminology for red cell surface antigens, Vox Sang, 87: 30416. 
[15] Reid, M. E. and Lomas-Francis, C. (2004). The Blood Group Antigen Facts Book, $\left(2^{\text {nd }}\right.$ ed). New York: Elsevier Academic Press.

[16] Uneke, C, J., Ogbu, O. and Nwojiji, V. (2006). Potential risk of induced malaria by blood transfusion in South-eastern Nigeria. Meagul J Med.9:8-13

[17] Cserti, C. M. and Dzik, W. H. (2007) The ABO blood group system and Plasmod Plasmodium falciparum Malaria. Blood; $110: 2250-2258$

[18] Alouch, A, L. (1997). Sickle cell disease and Malaria parasitaemia in a tropical setting Journ Biol. Chem. 12:23-30.

[19] Agbonlahor, D. E., Obi, F. I., Esumeh, O., Ajanaku, A. A. and Igumbor, E. O. (1993). Association of ABO blood Groups and malaria parasitaemia among students of Edo State University Ekpoma, Nigeria Journal of Medical Laboratory Scientist, 4(2): 12-19.

[20] Ruwende, C. and Hill, A. (1998). Glucose-6-phosphate dehydrogenase deficiency and malaria. Journ. Mol. Med. 76:581-588

[21] Sidhu, S and Sidhu, L. S. (1980). ABO blood group frequency among the sansis of Punjab. Coll. Anthropol. 4: 55-58.

[22] Kumar, R., Mukhopadhyayi, A. K and Rao, D. N. (2010). Characterization of an N6 adenine methyl transferase from Helicobacter pylori strain which methylates adjacent adenine. FEBS Journal. 277(7): 1666-1683.

[23] Blackwell, C. C., Dundan, S., Mackenzie, A. C., Braun, J. M and Alkrout, A. M. (2002). Blood Group and susceptibility to disease caused by Escherichia coli 0157. Journ. Infect. Dis. 185:393-396.

[24] Athreya, B. H. and Coriell, L. L. (1967). Relation of blood groups to infection. I. A survey and review of data suggesting possible relationship between malaria and blood groups. American Journal of Epidemiology, 86: 292-304.

[25] Singh, N., Shukla, M. M., Uniyal, V. P. and Sharma, V. P. (2003). ABO blood groups among malaria Cases from district Mandla, Madhya Pradesh. Indian J Malariol. ; 32:59-63.

[26] Ochei and Kolhatka. (2008). Medical laboratory science theory and practice. NewDelhi: Tata Mc Graw hill publishing company limited. 233-255.

[27] Fischer, P. R., and Boone, P. (1998). Short report: severe malaria associated with blood group. Am J Trop Med Hyg. 58:122-123.

[28] Lell, B., May, J., Schmidt-Ott, R. J. and et al. (1999). The role of red blood cell polymorphisms in Resistance and susceptibility to malaria. Clin Infect Dis. 28:794-799.

[29] Migot-Nabias, F, Mombo, L, E., Luty, A. J., Dubois, B., Nabias, R., Bisseye, C., Millet, P., Lu, C, Y. and Delovon, P. (2000). Human genetic factors related to susceptibility to mild malaria in Gabon. Genes Immun.1:435-44

[30] Pathirana, S. L., Alles, H. K., Bandara, S. and et al. (2005). ABO-blood-group types and protection Against severe, Plasmodium falciparum malaria. Ann Trop Med Parasitol. ; 99:119-124.

[31] Cserti-Gazdewich, C, M., Dhabangi, A., Musoke, C., Sewanyana, I., Mpimbaza, A. and Dzik, W. H. (2012). Cytoadherence in paediatric malaria: $\mathrm{ABO}$ blood groups and severe Plasmodium falciparum infection. British Journal of Haematology. 159: 223-236.

[32] Igbineghu, C., Odaibo, G. N., Olaleye, D, O. and Odiabo, A.(2012). Malaria infection and ABO blood Grouping in Iwo community, Southwestern Nigeria. Res. Journ. Med. Sci.6:247-250.

[33] Nasr, A. (2013). Blood group O protects against complicated Plasmodium falciparum malaria by the Mechanism of inducing high levels of antimalarial IgG antibodies. Saudi Arabia Journ. Med. 1:16-22.

[34] Beiguelman, B., Alves, F, P., Moura, M. M., Engracia, V., Nunes, A. C. S and Heckman, M. I. O. (2003). The Association of Genetic Markers and Malaria infection in the Brazilian Western Amazonian region. Mern lnst Oswaldo Cruv. 98:455-460

[35] Akhigbe, R. E., Ige, S. F., Afolabi, A. O., Azeez, O. M., Adegunlola, G. J. and Bamidele, J. O. (2009). Prevalence of haemoglobin variants, $\mathrm{ABO}$ and rhesus blood groups in Ladoke Akintola University of Technology, Ogbomoso, Nigeria. Trends Med Res, 4: 24-2.

[36] Tursen, U., Tiftik, En., Unal, S., Gunduz, O., Kaya, T. I. and Camdevinen, H. (2005). Relationship between ABO blood groups and skin cancers. Dermatol. Journ. 11:44-47

[37] Kassim, O. O., and Ejezie, G. C. (1982). ABO blood groups in malaria and schistosomiasis Haematobium. Acta Trop.; 39:179-184.

[38] Opera, K. N. (2007). Onchocerciasis and ABO blood group status; a field based study. Int J Trop Med.2:123-125.

[39] Abdulazeez, A. A., Alo, E. B. and Rebecca, S. N. (2008) Carriage rate of human immunodeficiency virus (HIV) infection among different $\mathrm{ABO}$ and rhesus blood groups in Adamawa State, Nigeria. Bio Med Res, 19: 41-44.

[40] Ndambaa, Y., Gonoa, E., Nyazemab, N., Makazaa, N. and Kaonarea, K. C. (1997). Schistosomiasis Infection in relation to the $\mathrm{ABO}$ blood groups among school children in Zimbabwe. Acta. Trop. 65:181-190.

[41] Herrera D, Druilhe P, Gentilini M, Eyquem A. (1982). High titres of anti-T antibodies and other haemagglutinins in human malaria. Clin Exp Immunol. 50:83- 91.

[42] Boel, M, E., Rijken, M, J., Pimanpanarak, M., Proux, S., Nosten, F and McGready, R. (2012). No association of phenotypic $\mathrm{ABO}$ blood group and malaria during pregnancy. American Society of Tropical Medicine and Hygiene.8:447-45

[43] Senga, E., Loscertales, M. P., Makwakwa, K. E., and et al. (2007). ABO blood group phenotypes Influence parity specific immunity to Plasmodium falciparum malaria in Malawian Women. Malar J.; 6:102-112.

[44] Rowe JA, Handel IG, Thera MA. (2007). Blood group O protects against severe Plasmodium falciparum malaria through the mechanism of reduced rosetting. Proc Natl Acad Sci. USA. 104:17471-17476.

[45] Otajevwo, F. (2013). Prevalence of malaria parasitaemia and its association with $\mathrm{ABO}$ blood grouping among students of Igbinedion University Okada, Nigeria. British Journal of Medicine and Medical Research. 3(4): 1164-1177. 
[46] Nkuo-Akenji, Paul, Wepngong. And Jane, F. A. (2004). Effects of ABO Rh blood groups G-6-P-D enzyme Acuity and haemoglobin genotypes on malaria parasitaemia and parasite density. Afr J Health Science. 11:93-97.

[47] Zerihum, Abraham, Degarege. and Berhanu Erko. (2011). Association of $\mathrm{ABO}$ blood group and Plasmodium falciparum malaria in done Bafeno area. Southern Ethiopia. Asia Journal of Tropical cell Biomedicine.6:289-294.

[48] Omotade, O. O., Adeyemo, A. A., Kayode, E., Falade, S, L and Ikpeme, S. (1999). Gene frequencies of ABO And RH (D) blood group alleles in a healthy infant population in Ibadan, Nigeria. West African Journal of Medicine. 18:294-297

[49] Brooks, G, F., Butel, J, S. and Morse, S. A. (2004). Medical parasitology $23^{\text {rd }}$ edition. McGraw Hill Companies. Inc. Boston; 818p

[50] World Health Organization. Communicable diseases cluster. Trans R Soc Trop Med Hyg. 1:90-94.

[51] Rosenfield, R. G. (1979). Blood typing and associated immunohemotological test procedures. In: manual of clinical immunology, American society for Microbiology, Washington, DC. $526: 111-230$

[52] Cheesbrough, M. (2000). Parasitological tests. District laboratory practices in tropic Countries, Cambridge University Press.221:23-45.

[53] Alemu, G and Mama, M. (2016). Assessing ABO/Rh Blood Group Frequency and Association with Asymptomatic malaria among Blood Donors Attending Arba Minch Blood Bank, South Ethiopia. Malaria Research and Treatment. 10: 1-7.

[54] Mandefro, A., Kelel, M. and Wessel, G. (2014). Association of $\mathrm{ABO}$ blood group and $\mathrm{Rh}$ factor with malaria and some gastrointestinal infectious disease in a population of Adet and Merrawi, Ethiopia. Global Journal of Biotechnology and Biochemistry. 9 (4); 137-142.

[55] Otajevwo, F. D and Igoniwari, S. F. (2014). Malaria parasitaemia association with $\mathrm{ABO}$ blood types among students of a private University in western Delta, Nigeria. Inter. Jour Trop Dis. and Health. 4(5): 67-76.

[56] Wazirzai, H., Ashfaque, A. and Herzig, J. W. (2005). Association of blood group A with increased risk coronary heart disease in the Pakistani population. Pakistan Journal of Physiology. 1(2): 1-3.

[57] Tadesse, H. and Tadesse, K. (2013). Assessing the association of severe malaria infection and $\mathrm{ABO}$ blood group in northwestern Ethiopia. Journal of Vector Borne Diseases. 50(4): 292-296.

[58] Getaneh, A and Mohammed, S. (2016). The prevalence of cardiovascular risk conditions and awareness among a Latino subgroup. Ethnicity and Disease Journ. 18(3): 342-347.

[59] Uzoegwu, P, N. and A. E. Onuwurah. (2003). Prevalence of heamoglobinopathy and malaria diseases in the population of old Aguata Division, Anambra state, Nigeria. Biokemistri. 15:57-66

[60] Anees, M. and M. S. Mirza. (2005). Distribution of ABO and $\mathrm{Rh}$ blood group alleles in Gujarat region of Punjab, Pakistan. Proc. Pak. Acad. Sci.42:233-238.

[61] Jeremiah, Z. A. (2006). Abnormal haemoglobin variants, ABO and $\mathrm{Rh}$ groups among student of African Descent in Port Harcourt. Africa. Health Si.6:177-181

[62] Bakare, A, A., M, A. Azeez and J. O. Agbolade. (2004). Gene frequencies of $\mathrm{ABO}$ and Rhesus blood Groups and haemoglobin variants in Ogbomosho, South-west, Nigeria global. J. Med. Sci.3:17-22

[63] Odokuma, E, I., A, C., Okolo. And P. C. Aloamaka. (2007). Distribution of $\mathrm{ABO}$ and Rhesus Blood groups in Abraka. Frequency of blood groups $\mathrm{ABO}$ and rhesus D in the Guinea population. Nig. J. Physiol. Sci.22:89-91

[64] Yuzhalin, A. E. and Kutikhin, A. G. (2012). ABO and blood groups in relation to ovarian, endometrial and cervical cancer risk among the population of the south-east Siberia. Asian Pacific Journal of Cancer Prevention. 13(10): 5091-5096.

[65] Mbanugo, J, I. and Emenalo, S. E. (2004). Prevalence of malaria parasitaemia among blood donors in Owerri, imo state, Nigeria. Nigeria Journal of Parasitology. 25:75-80.

[66] Mbanugo, J. I and Ejins, D. O. (2002) Plasmodium infections in children aged 0-5 years in Awka Metropolis, Anambra State, Nigeria. Nigerian Journal of Parasitology. 21:55-59.

[67] Nebe, O, J., Adeoye, G, O. and Agomo, P. U. (2002). Prevalence and clinical profile of malaria among the Coastal dwellers of Lagos state, Nigeria. Nigeria Journal of Parasitology. 23:61-68.

[68] Edington, G, M. and Gillies, H. M. (2001). Disease In: Pathology in the tropics. 121:234-245.

[69] Ahmed, S, G., Ibrahim, U, A. and Ibrahim, G. (2001). Prevalence and clinical significance of parasitaemia On blood donors in Maiduguri, Nigeria. Nigeria Journal of Parasitology. 22:29-34.

[70] Madhu G and Chowdhuri, A. N. R. (1980). Relationship between $\mathrm{ABO}$ blood groups and malaria. Bulletin of the World Health Organisation, 58 (6): 913-915.

[71] Portilo, W. R., and Sullivan, C. C. (1979). Genetic factors that influence immune regulatory potentials in females against some diseases. Journ Biotech. 2:111-115

[72] Beng-Ong R, Hill A. (1998). Glucose-6-phosphate dehydrogenase deficiency and malaria. J. Mol. Med. 76:581588 .

[73] Ochei and Kolhatka. (2008). Medical laboratory science theory and practice. NewDelhi: Tata Mc Graw hill publishing company limited. 233-255.

[74] Adam, I., Babiker, S., Mohammed, A. A., Salih, M. M., Prins, M. H and Zaki, Z. M. (2007). ABO Blood group system and placental malaria in an area of unstable malaria transmission In eastern Sudan. Malar J. 6:110-120.

[75] Amoo AL, Newbold CI, Marsh K. (1995). Plasmodium falciparum rosetting is associated with malaria severity in Kenya. Infect Immun. 63:2323-2326.

[76] Barragan, A., Kremsner, P. G., Wahlgren, M. and Carlson, J. (2000). Blood group A antigen is a Co receptor in Plasmodium falciparum rosetting. Infect Immun. 68:2971-2975.

[77] Carlson J, Walgreen M. Plasmodium falciparum erythrocyte rosetting is mediated by promiscuous lectin-like interactions. $J$ Exp Med. 1992; 176:1311-1317. 
[78] Rowe, A., Obeiro, J., Newbold, C. I. and Marsh, K. (1995). Plasmodium falciparum rosetting is Associated with malaria severity in Kenya. Infect Immun.; 63:2323-2326.

[79] Udomsangpetch, R., Todd, J., Carlson, J., and Greenwood, B. M. (1993). The effects of Hemoglobin genotype and ABO blood group on the formation of rosettes by Plasmodium falciparum-infected red blood cells. Am J Trop Med Hyg. 48:149-153

[80] Thakur, A., and Verma, I. C. (1992). Malaria and ABO blood groups. Indian J Malariol. 29:241- 244.
[81] Montoya, F., Restrepo, M., Montoya, A. E. and Rojas, W. (1994). Blood groups and malaria. Rev Inst Med Trop Sao Paulo. 36:33-38.

[82] Greene, J. O. (1993). Action Assembly perspective on social skill. Communicat. Theory. 3(1): 26-49.

[83] Carlson J and Walgreen M. (1993). Plasmodium falciparum erythrocyte rosetting is mediated by promiscuous lectin-like interactions. J Exp Med. 176:1311-1317. 